\title{
Assessment of pain and discomfort among agricultural workers involved in floriculture
}

\author{
ABHA SINGH, POONAM SINGH, PRAGYA OJHA AND MANISHA MISHRA
}

Received: 12.09.2016; Revised: 30.03.2017; Accepted: 16.04.2017

See end of the paper for authors' affiliations

\section{ABHA SINGH}

Department of Family Resource

Management, College of Home Science,

N.D. University of Agriculture and

Technology, Kumarganj, FAIZABAD (U.P.) INDIA
ABSTRACT : In Indian agricultural sector, lots of human resource is involved. Most of the agricultural activities are performed by rural women. The women are the backbone of agricultural workforce. In floriculture, more than half of the harvest and post harvest activities are performed by rural women. During these activities, rural women are involved in various kinds of drudgery prone activities for prolonged time. Keeping the above issues in mind, the present study was planned to assess the level of postural discomfort and musculoskeletal disorders among rural women involved in floriculture sector. The results revealed that more than half of the rural women $(59 \%)$ were suffering from hand and finger pain. Besides this, total 39 per cent rural women were suffering from back pain. Further, it was also observed that the main causes of postural discomfort and musculoskeletal disorders were manual operations, long working hours, prolonged activities and awkward working postures, lack of breaks, inadequate working environment, traditional agricultural tools and equipments. On the basis of present study, it was concluded that women friendly and drudgery reducing tools and technologies should be designed to reduce the level of postural discomfort, musculoskeletal disorders and human drudgery. Awareness programmes and trainings should be provided to empower the rural women at gross root level.

KEY WORDS: Women, Drudgery, Postural discomfort, Musculoskeletal disorders, Floriculture

- HOW TO CITE THIS PAPER : Singh, Abha, Singh, Poonam, Ojha, Pragya and Mishra, Manisha (2017). Assessment of pain and discomfort among agricultural workers involved in floriculture. Asian J. Home Sci., 12 (1) : 91-93, DOI: 10.15740/HAS/AJHS/12.1/91-93. 